\title{
穴が空いても自己修復するタイヤの開発*
}

\author{
長 屋 幸 助*1, 井 開 重 男*1 \\ 千葉学*2, 超 旭 京*2
}

\section{Tire with Self-Repairing Mechanism}

\author{
Kosuke NAGAYA*3, Sigeo IKAI, \\ Manabu CHIBA and Xujing CHAO \\ *3 Department of Mechanical Engineering, Gunma University, \\ 1-5-1 Tenjin-cho, Kiryu-shi, Gunma, 376-8515 Japan
}

\begin{abstract}
A new-type tire is presented, in which there is no air leakage when nails break the tire. The broken part is repaired automatically by its self-repairing mechanism. The self-repairing unit is consisting of two rubber sheets with lattices inside. Polymer particles, which expand their volume with water, are kneaded by bond, and inserted in the lattices. The unit is pasted to the inside wall of the tire. Coolant fluid diluted with water is inserted in the polymers uniformly. In this system, the polymer particles expand with water diluted coolant fluid, and become gel. Hence, they stop air leakages in the tire. Fundamental experiments are performed, and optimum conditions are found. This technique is also applied to real tires.
\end{abstract}

Key Words: Tire, Self Repairing, Non-air Leakage, Polymer

\section{1. 緒論}

パンクレスタイヤについては, 車の安全性の観点か ら古くから開発が行われさまざまな方式のものが考え られている. 古くには, 夕イヤの中に弾性のある柔ら かいゴム・ウレタンなどを充てんする方法が主流であ つたが, 路面からの振動伝達率が大きく, 乗り心地と 操縦安定性が悪く, 高速走行ができないという欠点が あった。すなわち, タイヤ内に空気を入れる方法が,

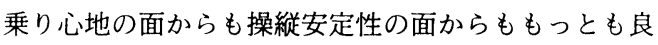
いとされている. 近年, 空気を入れたタイヤに対して, 空気圧を自動的に測定し, 送信するシステム(1), 夕イ ヤの圧力が安全な数值以下にならないように, 空気を 送り続ける装置を取付ける方法(2)など, 安全性をメン テナンスで保持する方法が提案されている。 また，二 輪車ではあるが, チューブのトレッドとショルダ部分 を空気室と液室の二重構造とし, 特殊なパンク防止液 を液室に製造段階で封入する構造のものも提案されて いる(3).しかし，この構造でも，サイド部に空いた穴

* 原稿受付 2003 年 7 月 24 日

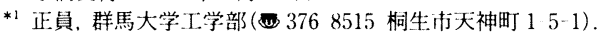

*2 群馬大学大学院 (-376 8515 桐生市天神町 $1-51$ ).

E-mail : nagaya (a me.gunma-u.ac.jp
あるいは夕イヤを貫通するほど長いくぎが刺さった場 合は，パンクとなる：二輪車については，さらに二重 構造のチューブ(4) も提案されているが，いずれもある 程度パンクの速度を遅くすることはできるが, 完全に 空気漏れを止めるものではない. そこで, パンクによ る空気漏れは仕方がないという発想に立ち, 空気漏れ を起こしてもある程度の距離走行できるランフラット タイヤも開発された．このタイヤはタイヤとリムの間 に特殊なメタルリングの装着, タイヤ側面の補強など をし，空気が抜けてしまっても車の重量を支えられる ようにしたもので, パンクが起こったあとでも最大 $200 \mathrm{~km}$ の走行を可能としている. しかし，この方法 でもある程度走行後はパンク修理が必要であり，また メタルリングの使用, ゴムの補強でタイヤの重量が増 すので，その分エネルギーロスがあり，乗り心地が悪 くなるという欠点がある.

上記のように，現在のタイヤ技術はタイヤの空気漏 れはあるので, パンクした場合, 空気の漏れをゆっく りとし，ある程度の距離走行できるという観点から盛 んに研究が行われている.しかし，もし，パンクして も即座にパンク穴を自己修復することができれば，パ ンク修理も必要ないし，また自己修復するシステムが 軽い弾性に富む材料でできていれば，エネルギーロス 
も小さく, 乗り心地も活とんど通常のタイヤと変わら なくできるが，このような観点からの研究は全くなさ れていない.

本研究では，パンクしてもパンク穴を即座に自己修 復するパンクレスタイヤを新たに開発するものであ る.すなわち, 本研究で開発したタイヤについて, そ の原理を明らかにして基礎的な条件を検討し，最適な 条件を求めるとともに，実際に本開発のパンクレスタ イヤを作りその性能試験を行った. その結果, 上記の ランフラットタイヤよりはるかに優れていることを明 らか比し。

\section{2. 本パンクレスタイヤの構造と 自己修復の原理}

本研究で開発したパンクレスタイヤの構造は図1に 示すようなもので, 通常のタイヤの内部に吸水パット とそれに接着したゴムシートがタイヤ内面に積層され て接着される。吸水パット妙 2 に示されるように 2 枚のゴムシートの間に接着剤で練られた粉末状の吸水

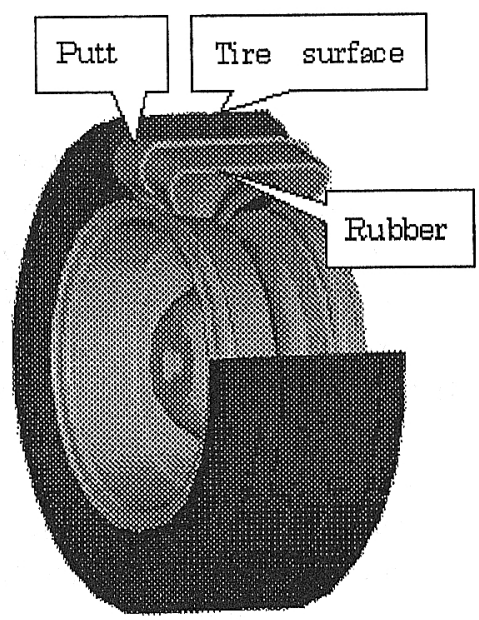

Fig. 1 Structure of the developed tire

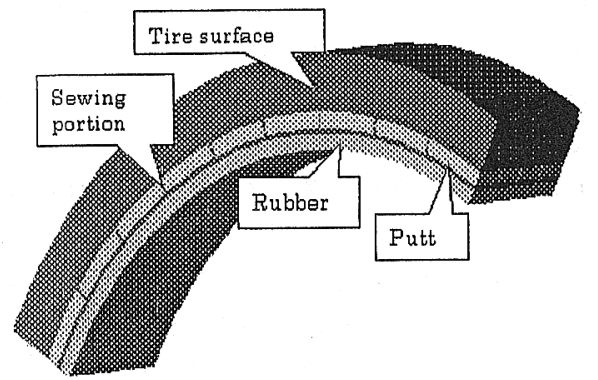

Fig. 2 Cross section of the tire with self repairing putt
ポリマがサンドイッチされており，適当な間隔で格子 状に上下面を縫い合わせてある(縫い目部分について は，次報で検討することとし，今回は考えない)。この 中に水を注入すると, 内部の吸水ポリマが半固体のゲ ル状になり膨脹する。このとき，吸水ポリマは格子内 に閉じこめられているので, 格子内部に膨潤圧が発生 する.また夕イヤ内部の空気圧で吸水パットの表面が 圧縮される．この状態で，タイヤ外側からくぎを刺す と，〈ぎの太さ分だけゲル化した吸水ポリマが押しの けられるが，くぎを扳いた瞬間に穴がゴムの弾性で小 さくなり，最終的に空けられた穴も膨潤圧とタイヤ内 空気圧 $q$ がゲル化した吸水ポリマに作用して瞬時に 塞ぐ (図 3 参照)。このとき, 吸水ポリマ内に穴がなく, 膨潤圧とタイヤ内压の和がタイヤ内圧より大きければ 空気は漏れないことになる.

しかし，空気漏れを防ぐのは漏水を止めるより難し く，下記に示すようにいくつかの課題がある.

吸水ポリマは粉末であるが，水を吸収すると半固体 のゲル状になり，形を変えて互いに接触してすきまを 塞ぐ.しかし，これに高圧の空気が流入すると，ポリ マが押しのけられて空気の流路が形成され, 空気漏れ が起こる.そこで, 吸水ポリマを適量の接着剤で練り, ゲル化したポリマの動きを固定する。これはまた，自
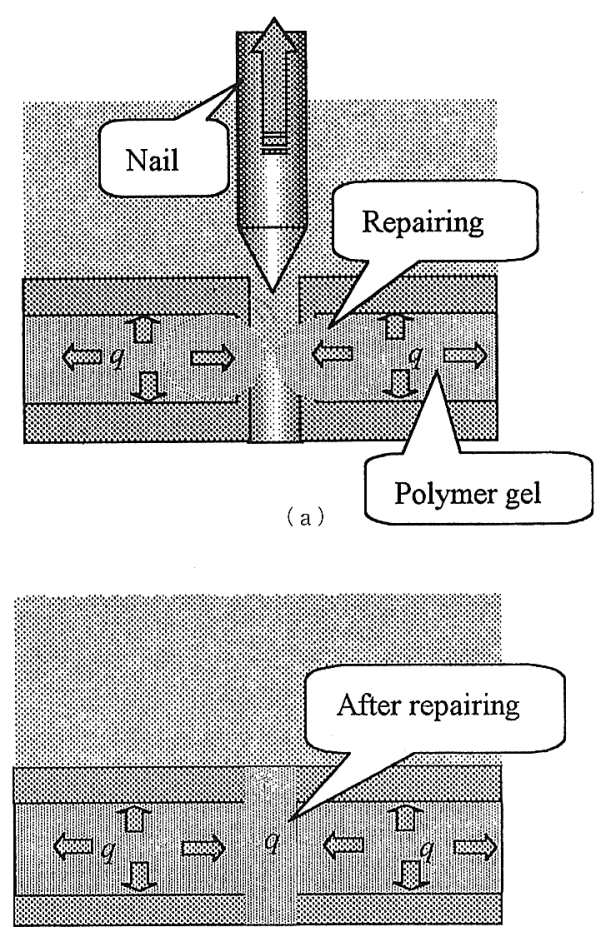

(b)

Fig. 3 Principle of self repairing 
動車が急加速・急減速したときにポリマが偏らないた めの有効な手段ともなる.このとき, 接着剤で練られ ゲル化したポリマはブチルゴムのように, 流動変形性 はあるが, 接着力のある半固体状のゲルとなっている ので, くぎにより空けられた程度の究から吸水ポリマ が外部へ漏れだすことはない. また接着剤は空気に触 れると硬化するので, 穴から侵入した空気により接着 剤が固められ穴を永久に塞ぐ。接着剤については, 後 述する熱に対しても安定であることが求められるが, 本実験では, 通常のゴムのりを用いる. ゴムのりは空 気に触れなければ硬化せず, かつ硬化速度が遅いので, 穴の修復までの短い時間に硬化せず, 穴修復後に硬化 が始まり,ゴム製のタイヤにもよく接着するので, 本 タイヤの接着剤としては適当である. またクーラント とゴムのりを混合した状態では, 長期間放置しても特 性の変化がほとんどないようで, 3 年間放置した後で も後述するような特性を保持していることを確認して いる. 接着剤を入れた場合, 吸水ポリマの表面が接着 剤でコーティングされるので, 吸水性が悪くなる.す なわち吸水ポリマの膨潤度が落ちる。したがって, 接 着剤の量については, ポリマを固定でき, かつ膨潤性 をあまり損なわない吸水ポリマと接着剤の適当な比率 が存在する.

自動車はかなり暑いところと寒いところで使用され る. また, 走行中のタイヤ内温度はかなり上昇する. したがって,ここで用いる吸水ポリマについては, 使 用中の温度に対して安定であり，かつ耐久性が要求さ れる. 本研究では, このことを考慮し吸水ポリマとし て, サンフレッシュ ST $500 \mathrm{D}$ (三洋化成)を用いる. この吸水ポリマの粒径は $150 \sim 710 \mu \mathrm{m}$ で, 自重の 400 倍の吸水性能があり, 温度の影響をほとんど受けず, PH 4〜10 の範囲で安定である.ただし, 紫外線で分 解し, 温度が $150^{\circ} \mathrm{C}$ 以上で放置すると, 吸水性能が減 少する.夕イヤ使用中の最大温度は $90^{\circ} \mathrm{C}$ 程度であり, 吸水パットをタイヤ内部に配置し, 紫外線を遮断する ことで, 本吸水ポリマを用いることができる.一方,

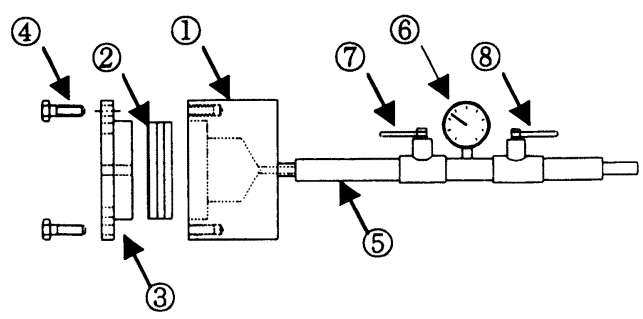

Fig. 4 System of pre-experimental equipment
吸水ブロックに注入される水は $+90^{\circ} \mathrm{C} \sim-40^{\circ} \mathrm{C}$ で蒸 発, 凍結しないことが必要であり, 通常の水は使用で きない.そこで, 本研究では, 蒸発が極めて少なく, かつ凍結しないクーラント液を水の代わりに用いる。 用いたクーラント液は, 通常のラジエータ冷却用のも ので，エチレングリコールが $95 \mathrm{wt} . \%$ に防さび材と消 泡材の混入したものである.クーラント液を水で 60\%程度までに薄めても上記の温度でほとんど蒸発と 凍結はない.クーラント液を用いた場合, 水より当然 のことながら吸水ポリマの膨潤度は落ちるが，それで も相当にポリマを膨脹させることができる.ポリマに 対するクーラント(水で薄めたクーラント)の量も重要 であり, クーラントの量が少なければ, 吸水ポリマの ゲル化が不完全で, 吸水パットの格子内部で大きな膨 潤圧が得られない. また，多すぎればゲルが水状にな り, 空気を通してしまう。したがって，ポリマとクー ラントの比率にも適当な值が存在する.

一方，ポリマの厚さ，すなわち，単位面積当たりの 吸水ポリマの量が多ければ多いほど空気漏れを防ぐ効 果は大きくなるが，その分夕イヤの価格は高くなり， 加えてタイヤ重量も増大する. したがって, ポリマの 量は少ないほうが良いが, その限界を調べる必要があ る.

以下, 上記のような問題点を実験により調べ, タイ ヤからの空気漏えいを遮断する良好な条件を探索す る.

\section{3. 実 験 装 置}

図 4 は実験装置の図を示したものである，図中(1)は 実験装置本体であり，アルミニウム製の円筒に穴が掘 られており，一端(左端)に試験片を入れる円形の段が 掘られている.その段の中に試験片(2)が入れられる. その試験片の上にふた(3)が被さりボルト(4)でふたを本 体に締付けて結合する．ふたの中心には直径 $8 \mathrm{~mm}$ の穴が空けられている，本体の他端にはホース(5)が結 合されており，ホースの中間に圧力計(6)と二つコッ ク(7)(8)が取付けられている.

図 4 でコック(7)と(8)を開放し, パイプ(5)の右端より コンプレッサで空気を入れ, コック 8)を閉じると, 本 体(1)内の空気圧が圧力計(6)に表示される.

図 5 は試験片の構造を分解して示したものである. この構成は図 1,2 の配置と基本的に同じであり, ベー スとなる厚さ $2 \mathrm{~mm}$ のゴム製円板(9)(ダイヤ表面層) の上に順次ゴム製リング10)(パットの側壁で, 試験器 からの空気漏れを防ぐ), 接着剂で練られた吸水ポリ マ(11), 厚さ $1 \mathrm{~mm}$ のゴム製円板(12)が接着され,一つの 
円板となる(これが図 1，20吸水パットに相当する)。 この円板を作った後に, 注射器で吸水ポリマ層(11に水 で薄めたターラント液をまんベんなく注入し，厚さ1 mmのゴム製円板(13)(図 1，2の内面ラバーに相当) 接着し，注射針でできた穴を塞ぐ。なお，ここで用い る接着剂以，市販のもので，ゴム(揮発)が 73.5 wt.\%， ノルマルへキサゴンが 20 wt.\%，天然ゴムほかが 6.5 wt.\%のもので, 吸水ポリマの昅水性能を残しつつ, 吸 水ポリマどうしを接着させる性貿がある。

図 5 でコック(7)と(8)開放し，パイプ(5)の在端より 空気を入れ，コック(8)を閉じると，本体(1)内の空気压 が王力計(6)に表示される。この状態で，ふた(3)に空け られた穴からくぎを，試験片を賁通するまで差し込ん でから引抜き，その後の空気压の変化を圧力計で調べ る。

\section{4. 実 験 結 果}

実験には, 直径 $3.4 \mathrm{~mm}, 4.2 \mathrm{~mm}, 5.25 \mathrm{~mm} の<$ ぎ，抢よび $6 \mathrm{~mm}$ のポンチの 5 種類の穴空け具(以下 すべてをくぎと総称する)を用意しこれれらで試験片 に穴を空けて空気の漏えいを調べる。

本方法で，ポリマに膨潤液を注入する量が多いほど， 膨潤圧が大きくなるが，瞦潤液の量が多くなるとダル が柔らかくなり空気の流入によりゲルが押しのけられ やすくなる。この動きを此めるためにゴムのりをポリ マに混入するが，このとき，同じ接着度に対し，水の 量が多くなるほど接着剮の量も多くしなければならな い.しかし，接着殽が多くなると，ポリマの吸水性が 悪くなるという関係がある。したがって，ポリマの量 に対し，镈潤液墨とゴムのりの量に適当な比率が存在

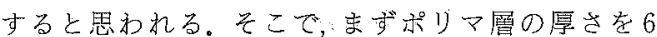
$\mathrm{mm}$ (面密度 $=0.407 \mathrm{~g} / \mathrm{cm}^{2}$ ) とし, $0.25 \mathrm{MPa}$ の空気圧 を与え, 直径 $3.4 \mathrm{~mm} の$ く学貴通させその後引抜い た。 5 時間経過後の試験容器内の圧力と接着凧の量 $p$

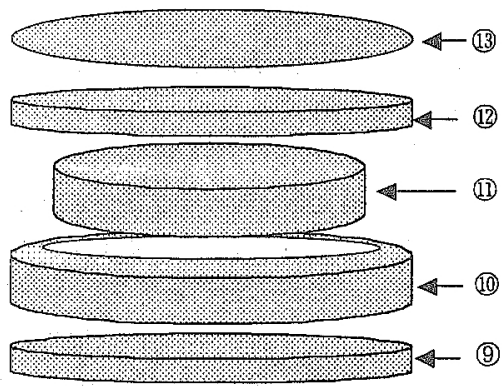

Fig. 5 Test piece used in the experiment
の関係を図 6 に示す。ここに, る接着郕の重量\%,同じく $w$ は膨潤液(クーラント $50 \%$, 水 $50 \%$ ：以下戦に水とも称する)の\%である。 容器内に与えた空気压が $0.25 \mathrm{MPa}$ であるので, 図中 $0.25 \mathrm{MPa}$ の值を示しているものは，5時間経過後も 空気漏れが全くなかったことを意味している。それよ り小さい值の場合は，空気漏れを起こしていることに なる。

図6から接着㓲の量が $20 \%$, 水の量が $60 \%$ よる゙ $80 \%$ ときは全く空気漏れがないことがわかる。さら に，接着剤の量が $30 \%$ ，水の量が $80 \%$ のきも空気漏 れがないことがわかる.これにより本方法で空気漏れ を防ぐことができるということがわかったが，ポリマ の厚さが $6 \mathrm{~mm}$ と厚い欠点がある. そこで, 以下, 空 気漏れのないことがわかった上記の 3 条件について, ポリマの厚さを薄くして烂しく実験を行った。

図 7 9 は吸水ポリマ層の厚さが $4 \mathrm{~mm}$ (面密度： $0.25 \mathrm{~g} / \mathrm{cm}^{2}$ )のときの試験器本体内圧力の時刻(単 位：h)変動を示したものである。ここに， $d[\mathrm{~mm}]$ は 試験片を買通させるとさのくざの太さ(直径)である. また, 戝 7〜9において, 試験器本体に入れる空気の初 期压力は, 烡用車の夕イヤを考慮し， $0.25 \mathrm{MPa} と し$ てある。

はじめに, 図6で空気漏れのなかったときの条件 ( $p=20 \%, w=80 \%)$ にいて，くぎの太さの及ぼす 条件を調べた，図 7 にその結果を示す. 図7で $d=$ $3.2 \mathrm{~mm}, d=4.2 \mathrm{~mm}$ では, 2 時間までは減左したが その後の減正はなく, $d=5.25 \mathrm{~mm}$ と $d=6 \mathrm{~mm}$ のと きの圧力は急減したが, その後自己修復することがわ かった。

くぎの直径 $6 \mathrm{~mm} 0$ 空気漏れが大きかったので, 接 着剂の量を増やし， $p=30 \%, w=80 \%$ 条件で同様の

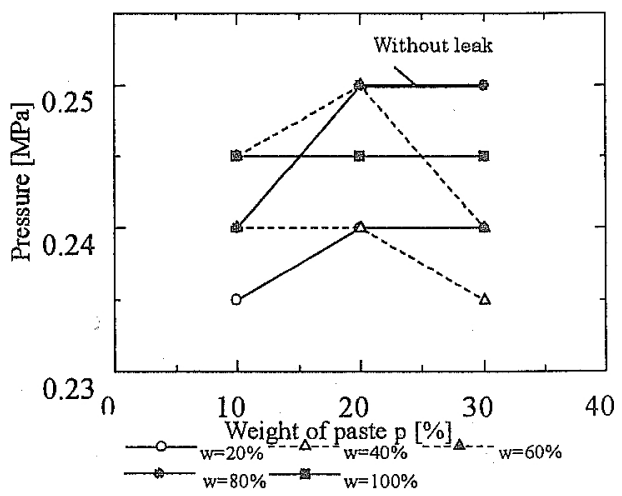

Fig. 6 Pressure versus weight percent of paste for $6 \mathrm{~mm}$ thickness test piece $(h=6 \mathrm{~mm})$ 
実験を行った(図 8)。このとき，くぎの直径 $6 \mathrm{~mm}$ の 場合のみ, 引抜いた瞬間にわずかな空気漏れが認めら れた。しかし, 空気漏れによる圧力変動はわずかに $2 \%$ 程度である。

水分を減らせば，接着剤の効果が増し，タイヤ重量 の減量と見込めると考え, $p=20 \%, w=60 \%, d=6$ $\mathrm{mm}$ の条件で実験を行った。結果を図 9 に示す。こ こには, 図 7,8 の結果も併せて示した。これより設定 した 3 条件の中で, $p=30 \%, w=80 \%$ の条件が最も優 れていることがわかる. なお, 図 8,9 で時間が零の点 に二つのデータがあるのは, 修復までの時間が短いた めにデータが同じ軸に重なったものである．このと き, 自己修復にかかる時間はくぎの直径が大きくなる と大きくなるが, 数秒から数十秒である.

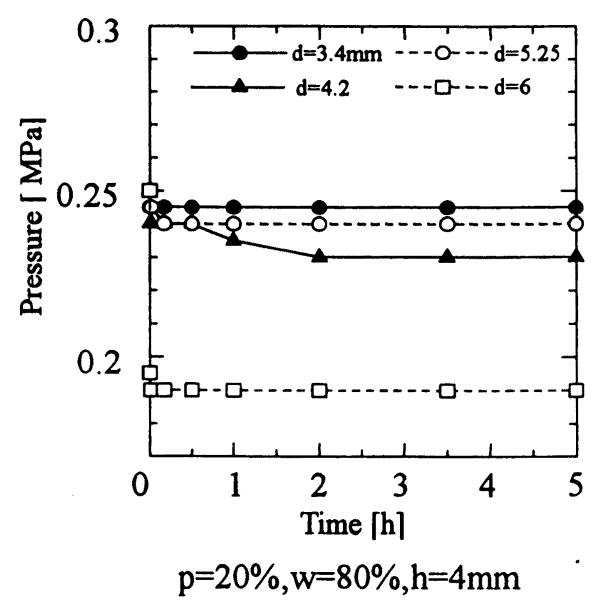

Fig. 7 Pressure versus time for various sizes of nails

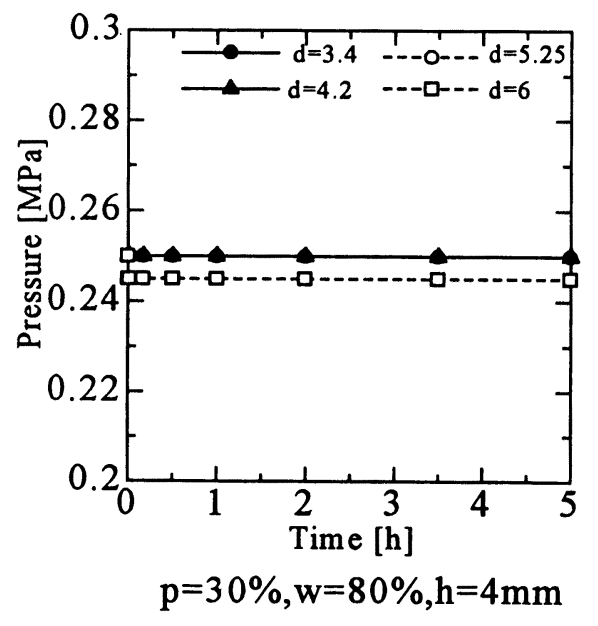

Fig. 8 Pressure versus time for various sizes of nail
以上より吸水ポリマの厚さが $4 \mathrm{~mm}$ でも空気漏れ を止めることができたので, 吸水ポリマの厚さが 2 $\mathrm{mm}$ (面密度: $0.125 \mathrm{~g} / \mathrm{cm}^{2}$ )の場合についても検討し てみた. 図 10 はポリマの厚みが $4 \mathrm{~mm}$ (実線)のとき と, $2 \mathrm{~mm}$ のとき(破線)について，くぎを引抜き，5時 間経過後の空気圧とくぎの直径の関係を示したもので ある。

この場合も接着剤の量が $30 \%$, 水の量が $80 \%$ の きが良好で，くざの太さが $4.2 \mathrm{~mm}$ 以下であれば, く ぎを抜いた瞬間に空気漏れが少し起こるが, その後は 穴を自己修復し, 空気漏れを起こさないことがわか る.しかし, それ以上くぎ径が太くなると, 空気圧が 零になるまで空気が抜けており, 実際のタイヤに適用 するには危険な領域である。

以上より, 吸水ポリマの厚さは $4 \mathrm{~mm}$ (面密度:

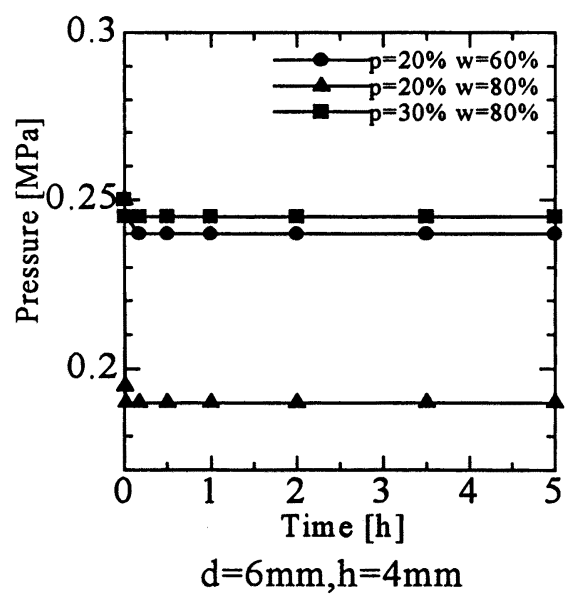

Fig. 9 Pressure versus time for various volumes of water

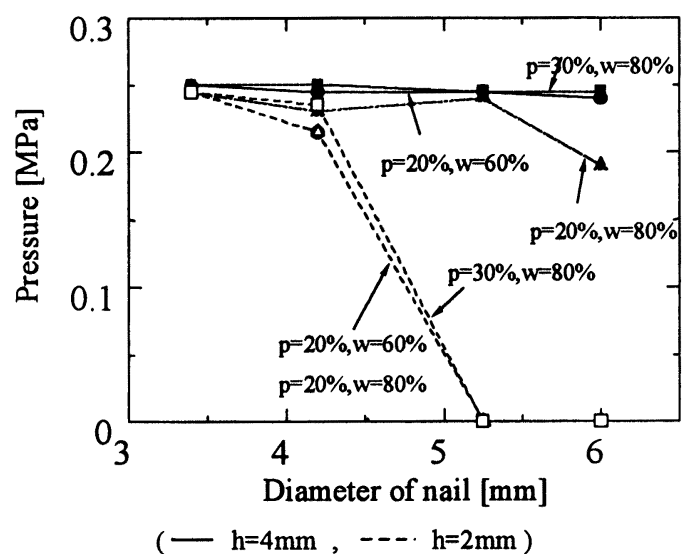

Fig. 10 Pressures versus nail diameters after five hours 
$\left.0.25 \mathrm{~g} / \mathrm{cm}^{2}\right)$ が適当といえる。

本研究では，吸水ポリマを用いたタイヤのパンクレ ス化が可能であることを示した基礎的実験であり，実 用化に対しては解決しなければならないいくつかの問 題がある。その一つが，縫い目にくぎが刺さった場合 の問題である。縫い目が拡大したとしても，その程度 の穴から空気漏れはないが, 縫い目部分は縫製時の圧 力で吸水ポリマが逃げるため, 薄くなり, その部分の 吸水ポリマが少なくなる。そのため, 縫い目にくぎが 刺さったときの空気漏えい遮断效果が小さくなる。し たがって，ネットを入れて縫い目厚を確保するなどの

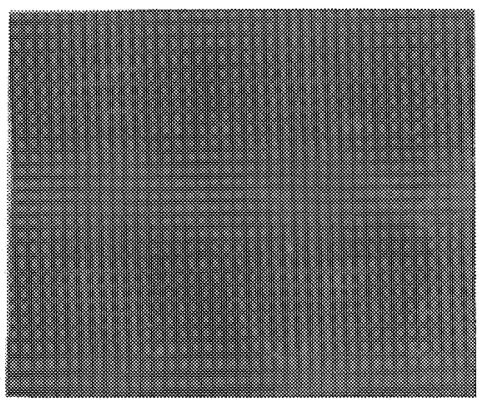

(a)

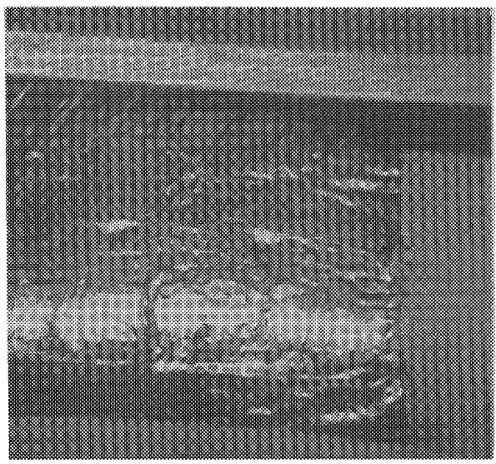

(b)

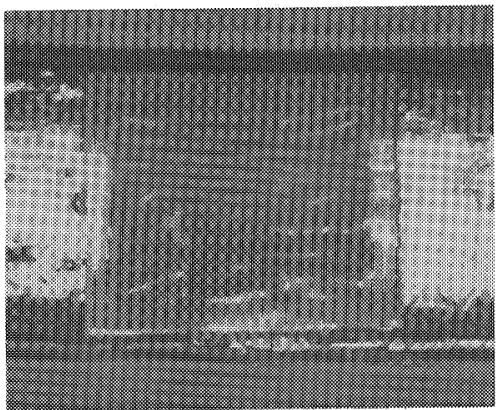

(c)

Fig. 11 Sequence of making non-puncture tire
縫い目厚確保の方法が必要であり，また，膨潤液混入 後の格子の凹凹は走行安定性を損なうので,一様な厚 さとする方法を確立する必要がある。

\section{5. パンクレスタイヤの試作と その性能試験}

$5 \cdot 1$ 静的試験以上の基礎実験より, 本研究で 提案した方法でパンクレスタイヤが可能との見通しが できた。そこで，実際にパンクレスタイヤを試作して みた。図 11 はタイの一部を本方法により，パンク レス化する順序を示したものである。

パンクレスの部分を作る工程は，まず，長方形穴が 空いたゴム板 (厚さ $4 \mathrm{~mm}$ )を薄いゴムシート(厚さ 1 $\mathrm{mm}) に$ 貼り付け，中にゴムのり $30 \%$ を混ぜた吸水ポ リマを入れて、ゴムシート(厚さ $1 \mathrm{~mm}$ )を被せて接着 し, 図11(a)のような正方形の格子に縫った吸水パッ 卜を作成する。市販タイヤの内面は平らではないの で，直接内面に上記吸水パットを貼り付けても，吸水 パットとタイヤ内面から空気漏れが起こるので，タイ ヤの内面に厚さ $1 \mathrm{~mm}$ のブチルゴムシートを貼り付 けて[図 11(b)]夕イヤ内面の凹凸を吸収する。その 上に製作した吸水パットを貼り付ける，続いて，吸水 パットの中に水で希釈したクーラント液を注射器でま んべんなく注入し [図 10（c）］，その上に薄いゴムシー 卜 (厚さ $1 \mathrm{~mm}$ )を接着する。このタイヤをホイールに 取付け，所定の圧力の空気を入れる。空気圧を観測す るため，空気挿入口に圧力計の取付けられたホースを 取付ける。

実験では，パンクレスの施されていない通常のタイ ヤと，上記のパンクレスの措置を施した 2 種類のタイ ヤを使用した。その実験結果を図 12 に示す。

まず,パンクレスの施していない通常のタイヤに $0.25 \mathrm{MPa}$ の空気を入れ, 直径 $3.4 \mathrm{~mm}$ のくぎを貫通 させ引抜いた後の压力を測定したところ，わずか 18 分で空気が抜け，圧力が零となることがわかった(図 12 の白丸印). 次いで, 初期圧力を $0.25 \mathrm{MPa} と し$, 直径 $5.25 \mathrm{~mm}$ のくぎで本パンクレスタイヤの吸水パ ットの部分に穴を空けたときの結果を求めたところ 500 分まではメータに現れるような空気漏れはなかっ た。そこで，日単位の計測を行った。その結果を図 12 右に示す。この図より 30 日間放置して 10\%程度の圧 力低下が認められる.

一方, トラックタイヤについては, 0.4 MPa 程度の 夕イヤ圧となるので, $0.4 \mathrm{MPa}$ ときの結果も求め た.図中白三角印はくぎの直径が $6 \mathrm{~mm}$ のときの結 果を表す。このときは，1回で穴を空けるの沈難しか 
ったので，まず直径 $3.4 \mathrm{~mm}$ で下穴を空け，そのあと 直径 $6 \mathrm{~mm}$ のくぎを貫通させ引抜いた.この場合, 残 念ながら約 500 分で空気が抜けてしまっている。そこ

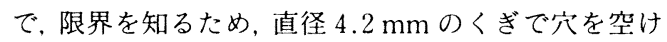
(1 回で穴を空けた), 引抜いた結果を求めた。図中の 黒丸印がその結果である。この場合は, 500 分経過後 で空気漏れはなく, 30 日間では約 $9 \%$ の圧力低下が認 められる。

以上のように非常に長い期間でほんのわずかではあ るが圧力低下が認められるが, このタイヤの自己修復 の完了したパンクの穴に洗剤をたらして空気漏れを検 定した限りでは, 全く空気漏れは観察されない。した がって, この圧力低下がパンクの穴によるものか, そ れとも圧力計の取付部から漏れているものなのかの検 定はできなかった。

$5 \cdot 2$ 実装試験(動的試験) 上記の試験は夕イヤ に穴を空けてそのまま放置したもので, 走行中に種々 の荷重を受ける実際のタイヤとは条件が異なる。そこ

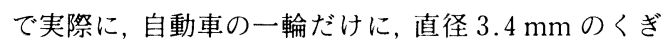
で穴を空けた本パンクヘスタイヤを装着し, 走行試験 を行った。この場合は, パンクレス化する部分の質量 分がアンバランスとなるので, パンクレス化した部分 をタイヤ直径上の一直線上 $\left(0\right.$ と $180^{\circ}$ の線上) に 2 箇 所作り, 回転のアンバランスができないようにした。

図 13 は走行試験の結果である。図 13 で左綐軸は夕 イヤ圧を, 右縦軸は自動車の走行距離を表し, 横軸は パンク穴を空けてからの経過日数である. 図中実線が 本パンクレスタイヤの結果を示し, 点線はパンク穴を 空けていない通常のタイヤの圧力変動を表す(ただし, 計測は実験開始時と 100 日経過後の 2 回の点を結んで (る)。まず, 通常の夕イヤでも 100 日走行で 0.01 $\mathrm{MPa}$ 程度の自然な圧力低下がある。一方本パンクレ スタイヤで $3.4 \mathrm{~mm}$ 直径のくぎを突き刺し, 抜いた後 の圧力変動は 60 日走行で約 $0.025 \mathrm{MPa}$ 程度であり,

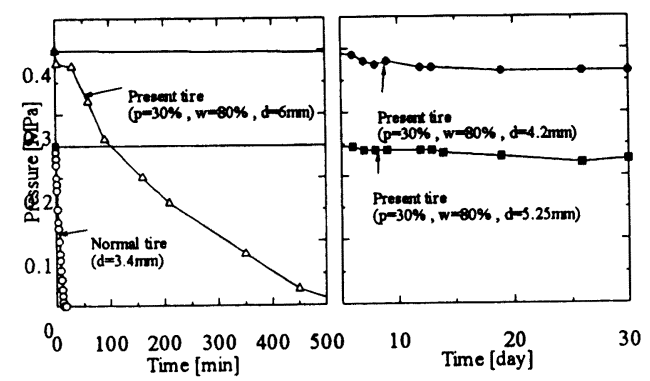

Fig. 12 Pressure versus time for the non-puncture tire

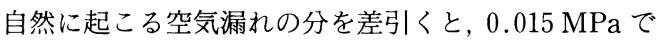
ある.この圧力低下はゲージを当てて圧力を計測する とき, どうしても空気漏れがあるために起こったもの と推定される.その理由は計測の回数とともに圧力は 低下しているが，60日から 100 日までの間に計測を行 わずに放置した場合は低力低下がほとんど認められな いことからもわかる.なお，微少な圧力変動は外気温 の変動によるものと考えられる.図 13 をた限り, 空気漏れはほとんどなく, パンク穴は完全に修復して いるといえる.

これまでのパンクレスタイヤで最も性能の良いラン フラットタイヤの場合では, パンクが起こってからの 限界走行距離は $200 \mathrm{~km}$ である(そのときの穴径と経 過時間は明らかにされていない). 本提案のパンクレ スタイヤは, 100 日間, 約 $3000 \mathrm{~km}$ の走行でも空気漏 れは発生しておらず，はるかにその性能を超えている ことがわかる。

なお, 本実験では, タイヤの一部にパンクレス化を 施したもので，吸水ポリマのない部分は当然のことな がら, 自己修復機能は存在しない.したがって, 実際 の夕イヤでは, 図 2 のように夕イヤ内面全周に吸水パ ットを貼り付けなければならない.また, タイヤにく ぎが刺さり，抜け落ちないでタイヤに刺さったままの ときは, くぎが抜け落ちたときよりも安全で, 空気漏 れが起きないことを確認している.さらに, 走行中に くぎ穴が拡大されることも考えられるが，くぎ穴が拡 大されたとき，タイヤとくぎの間の摩擦力が小さくな り，くぎは遠心力により抜け落ち，くぎ穴が極端に大 きくなることはないと思われる.

\section{6. 結 言}

本研究は，これまでにない原理に基づくパンクレス タイヤを新たに開発したものである.すなわち, 吸水 ポリマの膨潤圧により空気漏れを防止する方法を提案

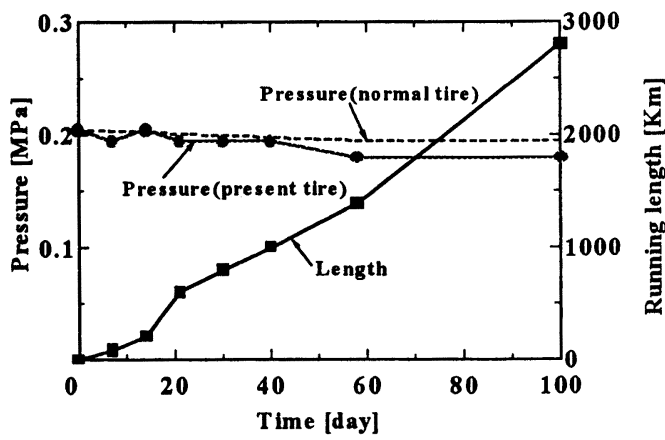

Fig. 13 The result of a mounting examination 
した．その基礎実験を行い，また実際にパンクレスタ イヤを製作してその性能試験を行ったものである．結 果を列記すると次のようである.

（1）本開発のパンクレスタイヤは, 吸水ポリマに 対する接着剤の比率および水の比率が重要であるが, 実験条件の中で良好であったものは接着剤の重量\%が $30 \%$, 膨潤液の重量\%が $80 \%$ のきである.

（2）吸水ポリマの厚さは厚ければ厚いほど良い が, 通常の乗用車およびトラックタイヤでは, 経済的 な面と走行安定性の面から考えて $4 \mathrm{~mm}\left(0.25 \mathrm{~g} / \mathrm{cm}^{2}\right)$ 厚程度が適当と思われる。

（3）以上の条件のもとで実際にタイヤを作ったと ころ, タイヤ圧が $0.4 \mathrm{MPa}$ (トラック用)のときは直径 $4.2 \mathrm{~mm}$ のくぎで穴を空けて引抜いても空気漏れはな く, また, 夕イヤ圧が $0.25 \mathrm{MPa}$ (一般乗用車用) のと きは, 直径 $5.25 \mathrm{~mm}$ のくぎで穴を空けて引抜いても 空気漏れはない.
（4）実際に，車に本タイヤを装着し，直径 3.4 $\mathrm{mm}$ のくぎで穴を空けて走行実験を行ったところ, 100 日間(走行距離約 $3000 \mathrm{~km}$ ) でも空気漏れがなか った.

\section{文献}

(1) Grossmann, R., Quartz Crystals as Remote Sensors for Tire Pressure, Conf. IEEE Instrummeas. Technol. Conf., 16-3 (1999), 1745-1749.

(2) Bradley, J., Eckhardt, L. and Soznala, F., Design of Emergency Tire Inflation System for Long-Haul Trucks, SAE Tech. Pap. Ser (Soc. Automot Eng.), SAE-95. 2592 (1995), 4.

（3）山際登志夫 - 中山研吾・清田悟 - 田中明子・橫坂昇, 二 輪車のパンク性向上チュープの開発, 自動車技術会講演 会前刷集, No. 976 (1997 10), 279-282.

（4）ホンダの2 輪技術 新しい防止液の効果, タフアップチ ューブでパンク率が激隇, 自動車と整備, 51-1 (1997), 4041. 